\title{
An analysis of the barriers of popularizing online purchasing among corporate sector managers in Sri Lanka \\ Kennedy D Gunawardana \\ University of Sri Jayewardenepura, Sri Lanka
}

\begin{abstract}
The purpose of this paper is to identify existing perceived barriers to popularizing online purchasing and to find out the relationship between perceived risk and popularizing online purchasing, with a specific focus on the influence of perceived risk. Moreover, this study aims to address on attitude towards the psychological and behavioural issues to gain consumer insights by which popularization of online transactions are most influenced. This paper tests a model of perceived risks as barriers to popularizing online purchasing. A questionnaire survey was used with a sample of 48 Sri Lankan corporate sector managers. The data was analysed using descriptive statistics and hypothesis testing. The perceived risk of issues of electronic payments, supply of personal information has a negative relationship with popularization of online purchasing. Non-online shoppers perceive higher risk than online shoppers while males perceive lower risk than females.
\end{abstract}

Key words-Online purchasing, Perceived risk, Popularization

\section{Introduction of the study}

Online retailing, which offers consumers a shopping experience distinct from physicalbased retailing, has been promoted in one form or another for more than 20 years (Westland and Au, 1997-1998). The term electronic commerce has become well known to everyone in the world with the continuous technical developments taken place over last few decades. By today it has become one of the most important aspects of the internet to emerge and to remain officially. E-commerce allows consumers to electronically exchange goods and services with no barriers of time or distance by allowing both consumers and sellers to mutually benefit by way of simplicity, convenience and variety of choice. Out of all e-commerce activities that can be identified, online purchasing holds a significant position as being the most attractive way of ecommerce.

Since the late 1990s, online shopping has taken off as an increasing number of consumers purchase increasingly diversified products on the Internet all over the world (Zhou et al, 2007). In a developing country like Sri Lanka, it is vital to see how online purchasing are being perceived by consumers, where people do not have much opportunities for online purchasing locally with compared to world context. As there are increasing opportunities for online retailers, the attention must be aimed at the fact that 
what online consumers matter when taking a purchasing decision.

Given that it is important knowing how to attract consumers for online retailers to be success, studies on consumer perception on online purchasing has attracted widespread attention. As online shoppers are known to be motivated to balance risks and benefits, risk perceptions of online consumers play a major role in explaining their purchasing behaviour and intention to continue online purchasing. This study aims at identifying the factors that are perceived to be riskier by online consumers and their influence on popularizing online purchasing. Studies of this nature have been conducted in some broader ways by many researches in many countries, but examining perceived barriers of popularizing online purchasing in Sri Lankan context is very limited.

When considering barriers to the stretching a concept like online purchasing, perceived risks takes an important place. As earlier research suggests risk of online shopping often a matter of perception in terms of security, privacy and trust considerations of consumers. Here throughout the study, three major risk considerations namely issue on electronic payments, supply of personal information and internet usage addiction will be taken in to considerations as they are more or less addressing behavioural and psychological aspects of consumers toward a buying decisions. Risk involving of each selected variable is determined by using approximately 5 areas that risk is expected to be arisen. The influence of those risk perceptions on popularization of online purchasing will be then examined in order to see the relationship between those two. We first discuss the theoretical background and early researches on perceived risk of online shopping, offering a rationale for the study. Second the findings of the quantitative study will be presented and finally a general discussion of the findings, implications and limitations of the study will be carried out.

In the light of the above discussion, the main objectives guiding the study are as follows.

- To find out existing perceived barriers of popularizing online purchasing

- To find out the relationship between perceived risk and popularizing online purchasing.

To this, end this study examines the risk perceptions of Sri Lankan corporate sector mangers towards acceptance and continuance of online purchasing. The scope of the study will be extended to psychological aspects of corporate sector managers on selected risk elements. However, this study is not focusing on the sectors in which managers are operating and is not undertaking a cross-cultural investigation. The sample consists with only corporate sector managers in Sri Lanka both who purchase online and not purchasing online. 


\section{Literature Review}

The purpose of the study was to investigate what are perceived barrier to internet usage and e-marketing by both users and nonusers. A detailed perceived risks map had been developed using descriptive statistics and hypothesis testing. They have suggested a model with the factors including both demographic traits and usage behaviour characteristics affecting the internet's perceived risk elements. The model had been tested against a sample of 465 employed adults from variety of organizations.

The data had been collected from a questionnaire survey covering different aspects of internet usage. Motives for shopping in traditional retail channels have long been a focus of consumer research. Bianchi \& Andrews, (2012). Identified two dominant shopping motives: shopping for fun and shopping with a goal in mind. Using a qualitative analysis, Wolfinbarger \& Gilly (2001) showed that these two motives are also typical of online shoppers. Hedonic shoppers are motivated by their involvement with a class of products that directs their browsing the internet through auction sites and visits to hobby-related sites. In other words, the hedonic shopper typically seeks a product specific online shopping experience. Goal-oriented shoppers are characterized by four motives for online shopping: convenience, in formativeness, selection, and the ability to control the shopping experience. There is considerable research to support their conclusion. For example, surveys conducted by the Graphics,
Visualization and Usability group at Georgia Tech (1994-1998) concluded that the web delivers convenience and time savings for the online shopper. Alreck \&Settle (2002) found that internet shopping was viewed as saving more time than traditional modes of shopping. Bianchi \& Andrews (2012) found that customers' perceived convenience of shopping on the internet had a positive impact on online purchase behaviour. However, Ratnasingam \& Pavlou (2003) found that for those who use online information sources for buying financial products, time availability was not associated with the propensity to conduct an online search for or purchase of these products.

Much of the literature examining factors that influence consumer attitudes and intentions towards purchasing online, including studies of perceived risk and trust, tend to focus on the initial adoption/nonadoption dichotomy (Forsythe, 2006). In contrast our study is based in the emerging area of interest related to post-adoption behaviour with interactive communication technologies (ICTs) and/or the technological delivery of digital products and services (Choi, 2011: Son \& Han, 2011: Andrews, 2012). Earlier studies also considered factors influencing continued use (Agarwal \& Prasad (1997); Parthasarathy \& Bhattacherjee, (1998); Karahanna, 1999; Andrews, 2007, Andrews, 2012), thus recognising the importance of confirmation and implementation behaviour in studying the diffusion of ICT innovations. However, 
these early studies took place in the emergence stage of ICTs where there was more focus on initial adoption and nonadoption, rather than continuance behaviour. Yet in the diffusion of innovation theory, continuation and confirmation of an innovation into everyday life is the most important stage of the diffusion cycle (Rogers, 1995). In line with this thinking recent researchers (e.g. Choi, 2011; Son \& Han (2011), Andrews, 2012) argue that studies on continuance behaviour are becoming increasingly important in this era of extensive acceptance and use of interactive communication. The risk perceptions of consumers play a major role in deciding online purchase decision. The theory of perceived risk has been applied to explain consumer's behaviour in decision making since the 1960s. Mitchell (1999) suggested that perceived risk is powerful at explaining consumers' behaviour because consumers are more often motivated to avoid mistakes than to maximise utility in purchasing (Hasin, 2008). The definition of perceived risk has changed since online transactions have become popular. In the past, perceived risks were primarily regarded as fraud and product quality (Wu \& Wang (2005), Hasin, 2008). Today, perceived risk refers to certain types of financial, product performance, social, psychological, physical and time risks when consumers make transactions online (Boksberger, 2007; Chang, 2008; Corbitt, 2003; Lim, 2003; Mitchell, 2001; Smith \& Sivakumar, (2004): Hasin, 2008). According to Kim (2007), perceived risk is defined as a consumer's belief about the potential uncertain negative outcomes from the online transaction. As perceived risk is an individual's biased assessment of a risk situation, its assessment is highly dependent on the individual's psychological and situational characteristics (Cho and Lee, 2006: Hasin, 2008). Accordingly, this study adopts perceived risk as a main factor to popularizing online purchasing.

Even though consumers perceive the Internet as offering a number of benefits, the Internet tends to magnify some of the uncertainties involved with any purchase process. Consumers perceive a higher level of risk when purchasing on the Internet compared with traditional retail formats (Lee and Tan, 2003; Tan, 1999). This is not surprising, since studies have consistently shown that consumers perceive higher risks in non-store shopping formats, such as telephone shopping (Akaah \& Korgaonkar, 1988), mail order (Van den Poel \& Leunis, 1999), catalogues (Eastlick \& Feinberg, 1999), and direct sales (Peterson, Albaum, \& Ridgway, 1989). Product performance and financial risk are two types of risk that have been associated with Internet shopping (Bhatnagar \& Ghose, 2004a, 2004b; Bhatnagar., 2000). Other studies (Forsythe, Petee, \& Kim, 2002; Forsythe \& Shi, 2003) have investigated the various types of risk perceived by Internet shoppers and found that three types of risk-product performance risk, financial risk and time/convenience risk-were related to 
frequency of online search with intent to purchase. Financial risk is defined as potential net loss of money (Derbaix:1983) and includes consumers' sense of insecurity regarding online credit card usage, which has been evidenced as a major obstacle to online purchases (Maignan and Lukas, 1997). Product performance risk, the loss incurred when a brand or product does not perform as expected (Horton, 1976), is largely due to the shoppers' inability to accurately evaluate the quality of the product online (Bhatnagar, 2000). Time/convenience risk includes the inconvenience incurred during online transactions, often resulting from difficulty of navigation and/or submitting orders, or delays receiving products (GVU, 1998). Currently, there is limited empirical evidence to indicate what types of risks have the greatest impact on Internet shopping behaviours. We expect that overall attitudes toward online shopping and online search/purchase behaviours will be influenced by consumers' perceptions of the risks associated with purchasing online.

\section{Research Methods}

\subsection{Data Collection Method}

A self-administrative questionnaire was used as the main data source for the study. The questionnaire was constructed with 24 questions which is a mixture of both demographic and Likert scale questions. The questionnaire consisting 5 demographic questions together with 19 questions with Likert scale that are aimed at collecting consumer insights was distributed among selected corporate sector managers. Likert scale questions were designed using attributes of independent variables and dependant variables by which the study purpose is expected to be covered. First, respondents were asked to express their experiences about using the internet in terms of usage frequency, comfort of usage and motivation for online purchasing. Second, respondents were asked to express their level of perception on selected three risk elements under a hypothetical online purchasing situation. All Likert scale questionnaire ranging 1 to 5 on each statement, with 5 representing the highest perceived risk and 1 indicating the lowest perceived risk.

\subsection{Types of variables}

Since the study examines the relationship between perceived risks and popularizing online purchasing, the dependent and independent variables were determined as popularizing online purchasing and perceived risk elements respectively. Issues on electronic payments, supply of personal information and internet usage addiction were identified as independent variables due to being main perceived risk elements. Two numerical variables were also used as age and monthly average income of the respondents. In addition to those, gender and shopping status (Online shopper/Nonshopper) were taken as categorical variables to the study.

\subsection{Hypotheses}

Hypotheses are as follows for the study.

H1. There is a negative relationship between perceived risk of issues on electronic 
payments and popularizing online purchasing

H2. There is a negative relationship between perceived risk of supply of personal information and popularizing online purchasing

H3. There is a negative relationship between perceived risk of internet usage addiction and popularizing online purchasing

H4. Non-online shoppers are likely to perceive higher risks in the internet than online shoppers

H5. Females are likely to perceive higher risks on online purchasing than males.

\subsection{Sample}

The sample was consistent with 48 corporate sector manages in Sri Lanka who is being employed in reputed large scale companies, located around the Colombo region. Convenient sampling was used as the main technique for developing the groups from the population to derive at a sample that contains homogenous characteristics. 60 managers of both male and female were picked out from the population and questionnaire was distributed. With a response rate of $82 \%, 49$ respondents were used for arriving at the findings. Since the study more concerns on privacy and financial security the sample was restrict only to corporate sector manager's despite of other considerations. The sample had mean age of 29 and most of the respondents were included in Rs. 50,000 - 100,000 income bucket. The mean education level of the sample recorded both academic and professional qualification.

\subsection{Data Analysis Methods}

Data analysis was carried out in two sections to wit descriptive statistics and hypotheses testing. All data analyses were performed using SPSS 16.0 software.

The demographic variables were analysed using measures of central tendency, distribution of individual variables and dispersion of variables. The descriptive analysis will provide a summary of basic features of the data and the sample. The scatter charts, histograms and other graphical representations have also been provided for explanatory purposes.

In order to verify the research hypotheses and question, the data was analysed in the following stages. First, independent sample t-tests were used to test H4 (Non-online shoppers are likely to perceive higher risks in the internet than online shoppers) and H5 (Females are likely to perceive higher risks on online purchasing than males). Then multiple linear regression models were used to test $\mathrm{H} 1, \mathrm{H} 2$ and $\mathrm{H} 3$, the relationships between perceived risk elements and popularizing online purchasing.

\section{Data analysis}

The chapter illustrates the findings of the study in two main sections to wit descriptive statistics and hypothesis testing. Data collected through self-administrative questionnaire survey were analysed using SPSS 16.0 version.

\subsection{Descriptive Statistics}

The demographic factors of the sample were 
analysed using descriptive statistics in order to provide basic features and a summary of the sample underlying the study. The each and every sample was analysed as follows.

\subsection{Gender}

Table 1

\begin{tabular}{|l|l|l|}
\hline & Frequency & Percent \\
\hline Male & 23 & 46.9 \\
Female & 26 & 53.1 \\
Total & 49 & 100.0 \\
\hline
\end{tabular}

The gender was taken as one of main categorical variables in the study. The sample was consistent with males and females in percentages of 46.9 and 53.1 respectively with high female participation. 23 males and 26 females have been selected in number. Moreover, it can be said that there is no much variation in percentage on males and females selected for the sample.

The mean age of the sample was 29.4 years and mode age of the respondents was 28 . As per the analysis, multiple modes were found as 29 and 28. According to the scatter diagram below most of the respondents were between 20-30 age categories even though a variance of 15 and standard deviation of 3.8 is shown. Therefore, it can be clearly seen that sample consists with young respondents. As earlier researches suggest young people have more intention to buy online.

\subsection{Education Level}

Table 2

\begin{tabular}{lll}
\hline & Frequency & Percent \\
\hline Academic only & 4 & 8.2 \\
Academic+ professional & & \\
Qualification & 22 & 44.9 \\
Professional Only & 23 & 46.9 \\
Total & 49 & 100.0 \\
\hline
\end{tabular}

When considering the education levels of the respondents, only professional qualifi cations holders represented the highest percentage. Academic qualifications plus professional qualifications holder's percentage is also similar to that. The histogram of education level of the respondents is as follow. As it shows more clearly the percentage of both academic + professional qualification holders and only professional qualification holders are much same.

\subsection{Income Level}

The income level is significant for acceptance a concept like online purchasing. Data on income level of respondents were analysed income range wise and represented through values as follows.

- 0 -Below Rs. 50,000

- 1 -Between Rs.50,000-100,000

- $\quad 2$-Between Rs. 100,000-200,000

- 3-Above Rs. 200,000

The recorded mean and mode of monthly average income level range was between Rs. 100,000-200,000. 


\section{Average Monthly Income}

Table 3

\begin{tabular}{|l|l|l|}
\hline & Frequency & Percent \\
\hline Below Rs 50000 & 7 & 14.3 \\
Rs 50000-100000 & 13 & 26.5 \\
Rs100000-200000 & 24 & 49.0 \\
Above Rs 200000 & 5 & 10.2 \\
Total & 49 & 100.0 \\
\hline
\end{tabular}

The above histogram shows the distribution of monthly average income. As we said earlier the popularization of online shopping showed significant differences within different income levels. The following results of one-way ANOVA test shows there is a significant difference within groups at the confidence level of $95 \%$.

Table 4

\begin{tabular}{|c|c|c|c|c|c|c|c|c|}
\hline & \multirow[t]{2}{*}{$\mathrm{N}$} & \multirow[t]{2}{*}{ Mean } & \multirow[t]{2}{*}{$\begin{array}{l}\text { Std: } \\
\text { Deviation }\end{array}$} & \multirow[t]{2}{*}{$\begin{array}{l}\text { Std: } \\
\text { Error }\end{array}$} & \multicolumn{2}{|c|}{$\begin{array}{l}95 \% \text { confidence interval for } \\
\text { mean }\end{array}$} & \multirow[t]{2}{*}{ Minimum } & \multirow[t]{2}{*}{ Maximum } \\
\hline & & & & & $\begin{array}{l}\text { Lower } \\
\text { bound }\end{array}$ & $\begin{array}{l}\text { Upper } \\
\text { bound }\end{array}$ & & \\
\hline Below Rs 50000 & 7 & 1.8000 & .46188 & .17457 & 1.3728 & 2.2272 & 1.00 & 2.40 \\
\hline Rs $50000-100000$ & 13 & 1.6462 & .43323 & .12016 & 1.9080 & 1.9080 & 1.00 & 2.80 \\
\hline Rs $100000-200000$ & 24 & 1.9500 & .74191 & .15144 & 2.2633 & 2.2633 & 1.20 & 3.80 \\
\hline \multirow[t]{2}{*}{ Above Rs 200000} & 5 & 2.8800 & 1.19666 & .53516 & 4.3659 & 4.3659 & 1.40 & 4.00 \\
\hline & 49 & 1.9429 & .75829 & .10833 & 2.1607 & 2.1607 & 1.00 & 4.00 \\
\hline
\end{tabular}

Table 5 Anova

\begin{tabular}{|l|l|l|l|l|l|}
\hline & Sum of squares & df & Mean square & $f$ & Sig \\
\hline Between groups & 5.680 & 3 & 1.893 & 3.887 & .015 \\
Within groups & 21.920 & 45 & .487 & & \\
Total & 27.600 & 48 & & & \\
\hline
\end{tabular}

$\mathrm{F}=3.887, \mathrm{p}<0.05$ 
4.5 Perceived risk of issues of Electronic payments, Supply of personal information,

\section{Internet usage addiction}

The risk perceptions of identified risk elements were analysed using frequency analysis in order to observe general idea of respondents on risk elements. The values for risk elements were given using a five point Likert scale as follows.

$$
\begin{array}{ll}
\circ & 1 \text {-Strongly lower Risk } \\
\circ & 2 \text {-Lower Risk } \\
\circ & 3 \text {-Moderate Risk } \\
\circ & 4 \text {-Higher Risk } \\
\circ & 5 \text {-Strongly Higher Risk }
\end{array}
$$

As you can see in table below, the average risk perception is around 3.6 for each element which means a high risk perception. Mode of the analysis also represents that most of the respondents perceive higher risk.

Table 6

\begin{tabular}{llll}
\hline & $\begin{array}{l}\text { perceived risks of issues } \\
\text { of electronic payments }\end{array}$ & $\begin{array}{l}\text { perceived risks of supply } \\
\text { of personal information }\end{array}$ & $\begin{array}{l}\text { perceived risks of internet } \\
\text { usage addiction }\end{array}$ \\
\hline & & & \\
Mean & 3.6071 & 3.5020 & 3.6694 \\
Mode & 4.00 & 4.00 & 4.20 \\
Std Deviation & .55668 & .48840 & .51080 \\
Variance & 310 & .239 & .261 \\
Skewness & -.922 & -.599 & -.468 \\
Total &. & & .340 \\
& 340 & 340 & \\
\hline
\end{tabular}

\subsection{Hypotheses Testing}

The developed five hypotheses were tested using independent sample t-tests and linear regression models. The section ahead describes test results and the findings of the study.

H1.There is a negative relationship between perceived risk of issues of electronic payments and popularizing online purchasing
The relationship between perceived risks of issues of electronic payments and the popularization of online purchasing among corporate level managers in Sri Lanka showed as negative. A linear regression model was developed to represent the relationship by taking perceived risks of issues of electronic payments as independent variable and popularization of online purchasing as dependant variable. 


\section{Regression test results}

Table 7 Model Summary

\begin{tabular}{|l|l|l|l|l|}
\hline Mode & R & R Square & Adjusted R Squre & Std Error of the Estimate \\
\hline 1 & $310^{\mathrm{a}}$ & .096 & .077 & .72847 \\
\hline
\end{tabular}

a. Predictors: (Constant), popularization of online purchasing

Table 8 ANOVA $^{\text {b }}$

\begin{tabular}{cllllll}
\hline Model & & Sum of Squares & df & Mean Square & F & Sig \\
\hline 1 & Regression & 2.658 & 1 & 2.658 & 5.009 & $.030^{2}$ \\
& Residual & 24.9425 & 47 & .531 & & \\
& Total & 27.600 & 48 & & & \\
\hline
\end{tabular}

a. Predictors: (Constant), perceived risks of issues of electronic payments

b. Dependent Variable: popularization of online purchasing

Table 9 Coeffificients ${ }^{\mathrm{a}}$

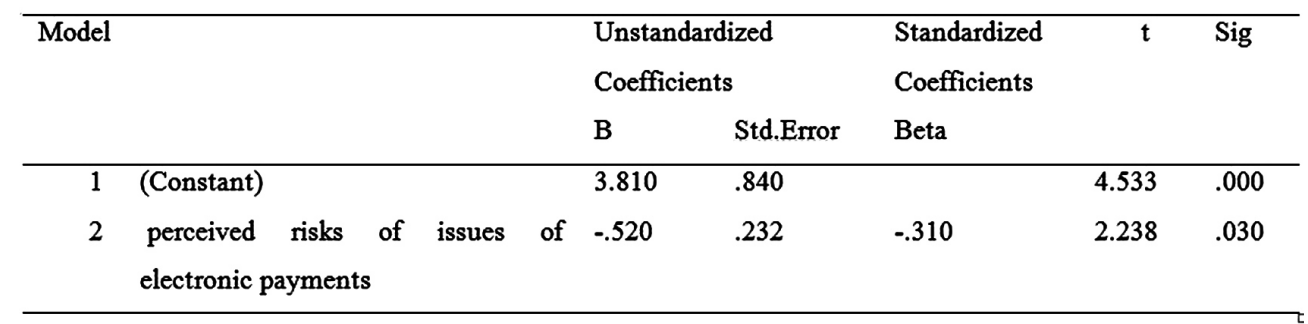

The significance value below 0.05 and high F static value (5.009) rejects the null hypothesis and

accepts the alternative hypothesis which means there is a relationship between perceived risks of issues of electronic payments and the popularization of online purchasing among corporate level managers in Sri Lanka. The coefficient of -0.520 proves that relationship is negative.
$\mathrm{H} 2$. There is a negative relationship between perceived risk of supply of personal information and popularizing online purchasing

The relationship between perceived risks of supply of personal information and the popularization of online purchasing among corporate level managers in Sri Lanka 
showed as negative. A linear regression model was developed to represent the relationship by taking perceived risks of supply of personal information as independent variable and popularization of online purchasing as dependant variable.

The significance value below 0.05 and high $\mathrm{F}$ static value (4.340) rejects the null hypothesis and accepts the alternative hypothesis which means there is a relationship between perceived risks of issues of electronic payments and the popularization of online purchasing among corporate level managers in Sri Lanka. The coefficient of -0.432 proves that relationship is negative.

Table 10 Model Summary

\begin{tabular}{|l|l|l|l|l|}
\hline Mode & R & R Square & Adjusted R Square & Std. Error of the Estimate \\
\hline 1 & $.291^{\mathrm{a}}$ & .085 & .065 & .73321 \\
\hline
\end{tabular}

Table 11 ANOVA $^{\mathrm{b}}$

\begin{tabular}{|c|c|c|c|c|c|}
\hline \multirow[t]{2}{*}{ Model } & \multicolumn{2}{|c|}{$\begin{array}{l}\text { Unstandardized } \\
\text { Coefficients }\end{array}$} & $\begin{array}{l}\text { Unstandardized } \\
\text { Coefficients }\end{array}$ & \multirow[t]{2}{*}{$\mathrm{t}$} & \multirow[t]{2}{*}{ sig } \\
\hline & B & Std. Error & Beta & & \\
\hline $\begin{array}{ll}1 & \text { (Constant) } \\
& \text { supply of personal } \\
& \text { information }\end{array}$ & $\begin{array}{l}3.527 \\
-.432\end{array}$ & $\begin{array}{l}.767 \\
.207\end{array}$ & -291 & $\begin{array}{l}4.596 \\
- \\
2.083\end{array}$ & $\begin{array}{l}.000 \\
.043\end{array}$ \\
\hline
\end{tabular}

a. Predictors :"(Constant), supply of personal information

b. Dependent Variable: popularization of online purchasing

Table 12 Coefficients

\begin{tabular}{cllllll}
\hline Model & & Unstandardized Coefficients & Unstandardized \\
& & t & soefficients \\
& & B & Std. Error & Beta & \\
\hline 1 & (Constant) & 3.527 & .767 & & 4.596 & .000 \\
& supply of personal information & -.432 & .207 & -.291 & -2.083 & .043 \\
\hline
\end{tabular}

a. Dependent Variable: popularization of online purchasing 
H3. There is a negative relationship between perceived risk of internet usage addiction and popularizing online purchasing

A linear regression model was developed to represent the relationship by taking perceived risks of internet usage addiction as independent variable and popularization of online purchasing as dependant variable. The third hypothesis was also tested using linear regression and the results of the study showed that there is no relationship between the perceived risk of internet usage addiction and popularizing online purchasing as presumed.

\section{Regression Results}

Table 13 Model Summary

\begin{tabular}{|l|l|l|l|l|}
\hline Mode & R & R Square & Adjusted R Squre & Std.Frror of the Estimate \\
\hline 1 & $112^{\mathrm{a}}$ & .013 & .008 & .76147 \\
\hline
\end{tabular}

Prēedictors: (Cónstant), perceived risk's of interñèt usage addiction "

Table 14 ANOVA $^{\mathrm{b}}$

\begin{tabular}{rllllll}
\hline Model & & Sum of Squares & df & Mean Square & F & Sig \\
\hline 1 & Regression & .347 & 1 & .347 & .599 & $.443^{\mathrm{a}}$ \\
& Residual & 27.253 & 47 & .580 & & \\
& Total & 27.600 & 48 & & & \\
\hline
\end{tabular}

a. Predictors: (Constant), perceived risks of internet usage addiction

b. Dependent Variable: popularization of online purchasing among corporate level managers

Table 15 Coeffificients ${ }^{\mathrm{a}}$

\begin{tabular}{rllllll}
\hline Model & & \multicolumn{2}{l}{ Unstandardized Coefficients } & Standardized Coefficients & $\mathrm{t}$ & Sig \\
& & $\mathrm{B}$ & Std.Error & Beta & & \\
\hline 1 & (Constant) & 2.553 & .796 & & 3.209 & .002 \\
& internet usage addiction & -.174 & .225 & -.112 & -.774 & .443 \\
\hline
\end{tabular}

a. Dependent Variable : popularization of online purchasing among corporate level managers 
The significance value above 0.05 and low $\mathrm{F}$ static value (0.599) accepts the null hypothesis and accepts the alternative hypothesis which means there is no relationship between perceived risk of internet usage addiction and the populari zation of online purchasing among corporate level managers in Sri Lanka.

Finally, a multiple regression model was

\section{Multiple regression results}

Table 16 Model Summary

\begin{tabular}{lllll}
\hline Mode & $\mathrm{R}$ & R Square & Adjusted R Squre & Std.Error of the Estimate \\
\hline 1 & $418^{\mathrm{a}}$ & 175 & .120 & .71146 \\
\hline
\end{tabular}

Predictors: (Constant), internet usage addiction, supply of personal information, issues of electronic payments

Table 17 ANOVA $^{\mathrm{b}}$

\begin{tabular}{rllllll}
\hline Model & & Sum of Squares & df & Mean Square & F & Sig \\
\hline 1 & Regression & 4.822 & 3 & 1.607 & 3.175 & $.033^{\mathrm{a}}$ \\
& Residual & 22.778 & 45 & .506 & & \\
& Total & 27.600 & 48 & & & \\
\hline
\end{tabular}

a. Predictors: (Constant), internet usage addiction, supply of personal information, issues of electronic payments

b. Dependent Variable: popularization of online purchasing

Table 18 Coeffificients ${ }^{\mathrm{a}}$

\begin{tabular}{|c|c|c|c|c|c|c|}
\hline \multirow[t]{3}{*}{ Model } & & \multirow{2}{*}{\multicolumn{2}{|c|}{$\begin{array}{l}\text { Unstandardized } \\
\text { Coefficients }\end{array}$}} & \multirow{3}{*}{$\begin{array}{l}\text { Standardized } \\
\text { Coefficients } \\
\text { Beta }\end{array}$} & \multirow[t]{3}{*}{$\mathbf{t}$} & \multirow[t]{3}{*}{ Sig } \\
\hline & & & & & & \\
\hline & & B & Std.Error & & & \\
\hline \multirow[t]{4}{*}{1} & (Constant) & 3.614 & .827 & & 4.371 & .000 \\
\hline & internet usage addiction supply of & .315 & .298 & -.203 & 1.054 & .297 \\
\hline & personal information & -.247 & .345 & -.166 & -.716 & .478 \\
\hline & issues of electronic payments & -.518 & .261 & -.380 & -1.987 & .053 \\
\hline
\end{tabular}

a. Dependent Variable : popularization of online purchasing 
The null hypothesis was rejected and there is a relationship between issues on Electronic payments, Supply of personal information, Internet usage addiction and the popularization of online purchasing.

H4. Non-online shoppers are likely to perceive higher risks in the internet than online shoppers

The study tries to identify the risk perception differences between online shoppers and non-online shoppers. An independent sample t-test was used to see whether there are significant differences between online shoppers and non-online shoppers towards the average risk perceptions of selected risk elements. A test variable was developed using average indices given on each risk elements and then tried to obtain an average opinion.

\section{t-test results}

Table 19 Group Statistics

\begin{tabular}{cclll}
\hline Online Shopper & $\mathrm{N}$ & Mean & Std. Deviation & Std. Error Mean \\
\hline Non Shopper & 11 & 3.9152 & .36282 & 1.0939 \\
Shopper & 38 & 3.4996 & .43678 & .07085 \\
\hline
\end{tabular}

Table 20 Independent Samples Test

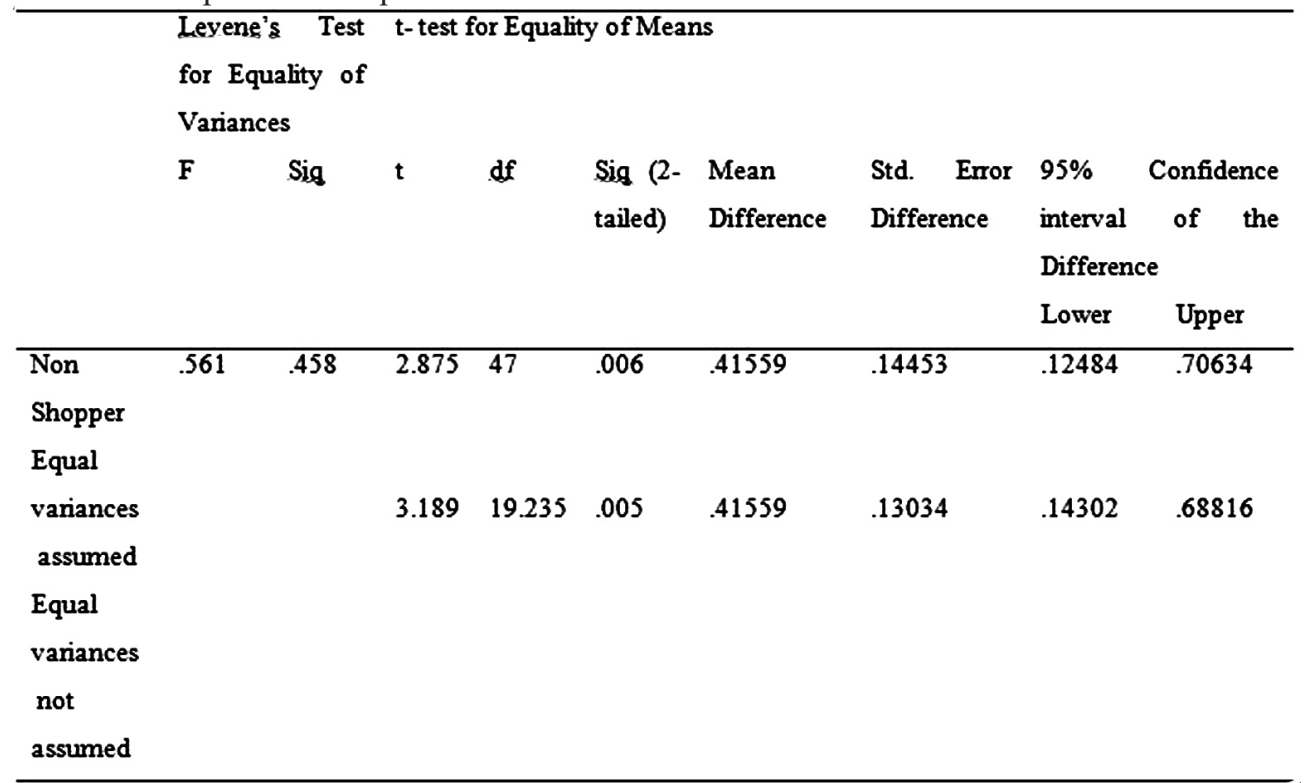

The value of sig (2-tailed) is below 0.05 , we can say that there is significant variance in risk 
perceptions according to the fact that consumers are shoppers or non-shoppers. The high mean of Non-online shopper says that non-online shoppers are likely to perceive higher risks in the internet than online shoppers. According to the t-test results we can reject the null hypothesis which means Non-online shoppers are likely to perceive higher risks in the internet than online shoppers.
H5. Females are likely to perceive higher risks on online purchasing than males. The study tries to identify the risk perception differences on gender wise. An independent sample t-test was used to see whether there are significant differences between males and females towards the average risk perceptions of selected risk elements. A test variable was developed using average indices given on each risk elements and then tried to obtain an average opinion.

\section{t-test results}

Table 21 Group Statistics

\begin{tabular}{ccccc}
\hline Gender & N & Mean & Std. Deviation & Std. Error Mean \\
\hline Non Shopper & & & & \\
Male & 23 & 3.3181 & .43467 & .09063 \\
Female & 26 & 3.8359 & .31112 & .06101 \\
\hline
\end{tabular}

Table 22 Independent Samples Test

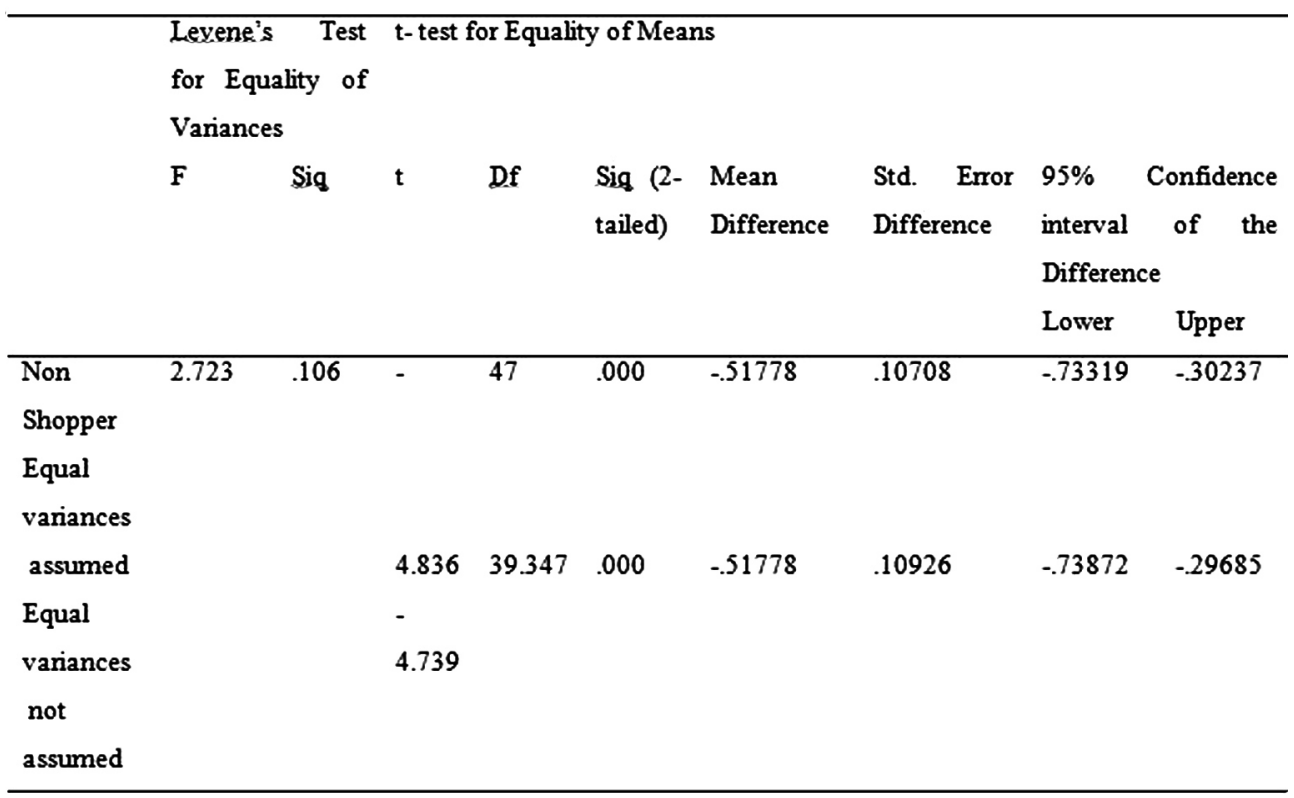


The value of sig (2-tailed) is below 0.05 , we can say that there is significant variance in risk perceptions on gender wise. The high mean of females says that females are likely to perceive higher risks in the internet than males. According to the t-test results we can reject the null hypothesis which means females are likely to perceive higher risks on online purchasing than males.

\section{Conclusion}

The research conducted was examined the risk perceptions of corporate managers in Sri Lanka that effects the popularization of online purchasing. The study results showed that perceived risk of electronic payments and risk of supply of personal information has a negative relationship with popularization of online purchasing. Further, results evident that the risk perceptions are significantly different gender wise and based on the fact that online shopper or non-online shopper. Accordingly, females perceive higher risk of online shopping than males and non-online shoppers perceive higher risk of online shopping than online shoppers. The main limitation uncounted with the study was generalizability of findings. Since the sample was selected only from Colombo region, geographical limitation is arisen. On the other hand, risks for popularizing of online purchasing are a multi-faceted concept. This study adopted only 3 risk elements.

In spite of its limitations, this study provides an exploratory attempt to examine some differences in perceived risk and relationship with popularizing online purchasing. The Internet simply widens the transactions between merchants and consumers to a global scale without any physical boundaries (Samiee, 2001, Shim,2009). Therefore, it is suggested that more research is required in order to understand the risk perceptions of online consumers a growing understanding of those perceived risks and gender differences will hopefully serve to make the Internet a friendlier, easily understood, and viable global shopping medium in the future.

\section{References}

Bianchi, C., \& Andrews, L. (2012). Risk, trust, and consumer online purchasing behaviour: a Chilean perspective. International Marketing Review, 29(3), 253-275.

Cases, A. (2002). Perceived risk and riskreduction strategies in Internet shopping. The International Review of Retail, Distribution and Consumer Research, 12(4), 375394.

Forsythe, S., Liu, Shannon, D., \& Gardner, L. (2006). Development of a scale to measure the perceived benefits and risks of online shopping. Journal of Interactive Marketing, 20(2), 55-75.

Harridge-March, S. (2006). Can the building of trust overcome consumer perceived risk online?. Marketing Intelligence and Planning, 24(7), 746-761. 
Chang, H., \& W. Chen, S. (2008). The impact of online store environment cues on purchase intention. Online Information Review, 32(6), 818841.

Ko, H., Jung, J., Kim, J., \& Shim, S. (2004). Cross-Cultural Differences in Perceived Risk of Online Shopping. Journal of Interactive Advertising, 4(2), 20-29.

Liebermann, Y., \& Stashevsky, S. (2002). Perceived risks as barriers to Internet and e-commerce usage. Qualitative Mrkt Res: An Int J, 5(4), 291-300.

Miyazaki, A., \& Fernandez, A. (2001). Consumer Perceptions of Privacy and Security Risks for Online Shopping. Journal of Consumer Affairs, 35(1), 27-44.

Pires, G., Stanton, J., \& Eckford, A. (2004). Influences on the perceived risk of purchasing online. Journal of Consumer Behaviour, 4(2), 118131.

Ratnasingam, P., \& Pavlou, P. (2003). Technology Trust in Internet-Based Interorganizational Electronic Commerce. Journal of Electronic Commerce in Organizations, 1(1),
17-41.

Sorce, P., Perotti, V., \& Widrick, S. (2005). Attitude and age differences in online buying. Intl $J$ of Retail and Distrib Mgt, 33(2), 122-132.

Stone, R., \& Grønhaug, K. (1993). Perceived Risk: Further Considerations for the Marketing Discipline. European Journal of Marketing, 27(3), 39-50.

Westland, J.C., \& Au, G. (1997-1998). A comparison of shopping experiences across three competing digital retailing interfaces. International Journal of Electronic Commerce, 2(2).

Youn, S. (2005). Teenagers' Perceptions of Online Privacy and Coping Behaviors: A Risk-Benefit Appraisal Approach. Journal of Broadcasting and Electronic Media,49(1), 86-110.

Zhou, L., Dai, L., \& Zhang, D. (2007), Oneline Shopping Accepance Model-A Critical Survey of consumer Factors in Online Shopping, Journal of Electronic Commerce Research, 8(1). 